\title{
LIN28A immunoreactivity is a potent diagnostic marker of embryonal tumor with multilayered rosettes (ETMR)
}

\author{
Andrey Korshunov $\cdot$ Marina Ryzhova $\cdot$ David T. W. Jones $\cdot$ Paul A. Northcott $\cdot$ Peter van Sluis $\cdot$ \\ Richard Volckmann · Jan Koster · Rogier Versteeg • Cynthia Cowdrey • Arie Perry • Daniel Picard • \\ Marc Rosenblum • Felice Giangaspero • Eleonora Aronica • Ulrich Schüller • Martin Hasselblatt • \\ V. Peter Collins $\cdot$ Andreas von Deimling $\cdot$ Peter Lichter $\cdot$ Annie Huang $\cdot$ Stefan M. Pfister $\cdot$ Marcel Kool
}

Received: 22 October 2012/Revised: 6 November 2012/ Accepted: 6 November 2012/Published online: 16 November 2012

(C) The Author(s) 2012. This article is published with open access at Springerlink.com

\begin{abstract}
Embryonal tumor with multilayered rosettes (ETMR, previously known as ETANTR) is a highly aggressive embryonal CNS tumor, which almost exclusively affects infants and is associated with a dismal prognosis. Accurate diagnosis is of critical clinical importance because of its poor response to current treatment protocols and its distinct biology. Amplification of the
\end{abstract}

A. Korshunov · A. von Deimling

Clinical Cooperation Unit Neuropathology, German Cancer

Research Center (DKFZ), Im Neuenheimer Feld 280,

Heidelberg, Germany

\section{Ryzhova}

Department of Neuropathology, NN Burdenko Neurosurgical Institute, 4th Tverskaya-Yamskaya 16, Moscow 125047, Russia

D. T. W. Jones · P. A. Northcott · S. M. Pfister · M. Kool ( $₫)$ Division of Pediatric Neurooncology, German Cancer Research Center (DKFZ), Im Neuenheimer Feld 580 69120,

Heidelberg, Germany

e-mail: m.kool@dkfz.de

P. van Sluis · R. Volckmann · J. Koster - R. Versteeg

Department of Oncogenomics, Academic Medical Center,

Amsterdam, The Netherlands

C. Cowdrey · A. Perry

Departments of Pathology and Neurological Surgery,

Brain Tumor Research Center, University of California,

San Francisco, USA

\section{Picard · A. Huang}

Division of Hematology-Oncology, Department of Pediatrics, Arthur and Sonia Labatt Brain Tumour Research Centre, Hospital for Sick Children, University of Toronto,

Toronto, ON, Canada

M. Rosenblum

Department of Pathology, Memorial Sloan-Kettering Cancer

Center, New York, USA
miRNA cluster at 19q13.42 has been identified previously as a genetic hallmark for ETMR, but an immunohistochemistry-based assay for clinical routine diagnostics [such as INI-1 for atypical teratoid rhabdoid tumor (AT/ RT)] is still lacking. In this study, we screened for an ETMR-specific marker using a gene-expression profiling dataset of more than 1,400 brain tumors and identified

F. Giangaspero

Department of Radiological, Oncological and Anatomic

Pathology Sciences, Università Sapienza, Rome, Italy

F. Giangaspero

IRCCS Neuromed, Pozzilli, Italy

E. Aronica

Department of Neuropathology, Academic Medical Center, Amsterdam, The Netherlands

U. Schüller

Center of Neuropathology, Ludwig-Maximilians University,

Munich, Germany

M. Hasselblatt

Institute of Neuropathology, University Hospital Münster,

Münster, Germany

V. P. Collins

Department of Pathology, University of Cambridge, London, UK

P. Lichter

Divison of Molecular Genetics, German Cancer Research Center (DKFZ), Heidelberg, Germany

S. M. Pfister

Department of Pediatric Hematology and Oncology, Heidelberg University Hospital, Heidelberg, Germany

A. Korshunov · A. von Deimling

Department of Neuropathology, Heidelberg University Hospital, Heidelberg, Germany 
LIN28A as a highly specific marker for ETMR. The encoded protein binds small RNA and has been implicated in stem cell pluripotency, metabolism and tumorigenesis. Using an LIN28A specific antibody, we carried out immunohistochemical analysis of LIN28A in more than 800 childhood brain-tumor samples and confirmed its high specificity for ETMR. Strong LIN28A immunoexpression was found in all 37 ETMR samples tested, whereas focal reactivity was only present in a small (6/50) proportion of AT/RT samples. All other pediatric brain tumors were completely LIN28A-negative. In summary, we established LIN28A immunohistochemistry as a highly sensitive and specific, rapid, inexpensive diagnostic tool for routine pathological verification of ETMR.

Keywords ETMR - Pediatric brain tumor - LIN28A . Diagnostic marker

\section{Introduction}

Embryonal tumor with multilayered rosettes (ETMR), also previously reported as embryonal tumor with abundant neuropil and true rosettes (ETANTR) is a rare, albeit likely underdiagnosed embryonal CNS neoplasm with fewer than 100 cases reported in the literature since its initial description in 2000 [3, 5, 19]. In the 2007 WHO classification, ETANTR was only discussed as a possibly unique variant of CNS tumors [14]. Supratentorial localization has mainly been reported, but it may also occur in the brain stem and cerebellum [3, 5, 11]. ETMR predominantly affects children under the age of 3-4 years and is associated with a highly aggressive disease course with reported overall survival times ranging from 5 to 30 months. The histopathological appearance is distinctive in its mixture of poorly differentiated small cell areas with prominent multilayered (ependymoblastic) rosettes, and areas with focal neuronal differentiation, thus combining features of CNS neuroblastoma and ependymoblastoma $[3,5,11]$. On the other hand, a wide spectrum of morphological patterns may be encountered, with some features being considerably less specific. For this reason, misdiagnosis is not uncommon, with common considerations including "small round blue cell tumor, not otherwise specified", i.e., central nervous system primitive neuroectodermal tumors (CNS PNET) including controversial variants (e.g., ependymoblastoma, central neuroblastoma), medulloblastoma, and anaplastic ependymoma [9, 13, 25]. Moreover, similar rosettes can sometimes occur in other embryonal CNS tumors (e.g., CNS PNET, AT/RT) [7]. Nevertheless, accurate pathological verification of ETMR is of important clinical relevance, given its poor response to current CNS PNET treatment protocols and thus universally fatal outcome $[5,11,13]$. Amplification of a miRNA cluster at $19 \mathrm{q} 13.42$ has been identified as a genetic hallmark of ETMR, affecting up to $95 \%$ of samples tested and it is considered a unifying molecular diagnostic marker for these tumors [11, 13, 16, 25].

However, the requirement of non-commercial custom made BAC probes for FISH testing renders this assay virtually inaccessible to nearly every pathology laboratory around the globe. In contrast, the use of immunohistochemistry is universally utilized in neuropathology centers everywhere. As such, ETMR is a highly attractive target for developing tumor-specific immunohistochemistry. For this purpose, we herein performed a screen for ETMRspecific genes based on gene expression profiles collected for a large cohort of various brain tumors $(n=1,404)$. We selected the most specifically expressed gene, namely LIN28A, and subsequently tested its diagnostic specificity for ETMR with a high-quality commercial antibody on a large cohort $(n=816)$ of paraffin-embedded brain tumors. Our results show that LIN28A expression can be used as a specific diagnostic biomarker to detect ETMR.

\section{Materials and methods}

To find ETMR specific marker genes, we used 849 publicly available gene expression profiles $[1,4,6,8,10,17,18,21$, $23]$ plus 555 newly generated profiles (total 1,404 ) of primary pediatric and adult brain tumors including low-grade glioma (LGG; $n=7$ ), pilocytic astrocytoma (PA; $n=$ 129), ependymoma (EP; $n=162$ ), astrocytoma grade II (AII; $n=22$ ), oligodendroglioma grade II (OII; $n=47$ ), oligoastrocytoma grade II (OAII; $n=3$ ), anaplastic astrocytoma grade III (AAIII; $n=49$ ), anaplastic oligodendroglioma grade III (AOIII; $n=60$ ), anaplastic oligoastrocytoma grade III (AOAIII; $n=25$ ), glioblastoma grade IV (GBM; $n=349$ ), diffuse infiltrating pontine glioma (DIPG; $n=29)$, CNS PNET $(n=43)$, atypical teratoid rhabdoid tumor (AT/RT; $n=37)$, medulloblastoma (MB; $n=429)$, and ETMR $(n=13)$. All geneexpression profiles were generated by Affymetrix U133plus 2.0 arrays using RNA isolated from frozen tumors. For comparison we used the publicly available gene expression profiles of 353 normal CNS and non-CNS tissues [22]. All data were analysed using the microarray analysis and visualization platform R2 (http://r2.amc.nl). For immunohistochemical (IHC) analysis of LIN28A, a polyclonal antibody (A177, \#3978, Cell Signaling Inc, Boston, MA, USA) was applied to a partly overlapping ( $\sim 10 \%$ of the cases was also included in the expression profiling) cohort of 816 malignant pediatric brain tumors constructed on tissue microarrays (patient age $<18$ years; see Table 1 ), including MB $(n=334) ;$ EPIII $\quad(n=223) ; \quad$ GBM 
Table 1 Distribution of LIN28A immunoexpression in various pediatric brain tumors

\begin{tabular}{lcllll}
\hline Tumor type & $n$ & LIN28A + diffuse & LIN28A + focal & INI1 negativity & 19q13.42 amplification \\
\hline ETMR & 37 & $37(100 \%)$ & 0 & 0 & $36(97 \%)$ \\
AT/RT & 50 & 0 & $6(12 \%)$ & $50(100 \%)$ & 0 \\
stPNET & 41 & 0 & 0 & 0 & 0 \\
MB & 334 & 0 & 0 & 0 & 0 \\
EPIII & 223 & 0 & 0 & 0 & 0 \\
GBM & 131 & 0 & 0 & 0 & 0 \\
\hline
\end{tabular}

( $n=131)$; AT/RT $(n=50)$; CNS PNET $(n=41)$; ETMR $(n=37)$. All cases, except for a few ETMR cases contributed by collaborators, were obtained from the NN Burdenko Neuropathological Institute (Moscow, Russia). IHC was performed with an automated stainer (Benchmark; Ventana XT) using antigen-retrieval protocol CC1 and a working antibody dilution of 1:100 with incubation at $37{ }^{\circ} \mathrm{C}$ for $32 \mathrm{~min}$. In parallel, FISH analysis for the 19q13.42 locus was performed for all tumors as previously described [11].

\section{Results and discussion}

As an initial step, a comparative supervised analysis of gene-expression profiles generated for a large cohort of various pediatric and adult brain tumors was performed. When comparing the 13 ETMR samples with all other brain tumors, we identified a specific gene signature that could readily distinguish ETMR samples from all other brain tumors. Among the 50 most differentially expressed genes, 18 (LIN28A, IGF2BP1, CRYBA1, HIC2, PRPF31, SALL4, SHISA3, HMGA2, LOC440416, PRTG, LOC253842, DNMT3B, CRABP1, C2ORF29, MRPS9, $F G F B P 3, S P 8$, and HES5) were highly upregulated in all ETMR samples. However, only one gene, LIN28A, was highly upregulated in ETMR but not in any other brain tumor (Fig. 1). Nine ETMR samples showed particularly high LIN28A expression (>1,000). For all other brain tumors, only a subset of AT/RTs and a few other tumors showed low LIN28A mRNA levels, but otherwise, it was

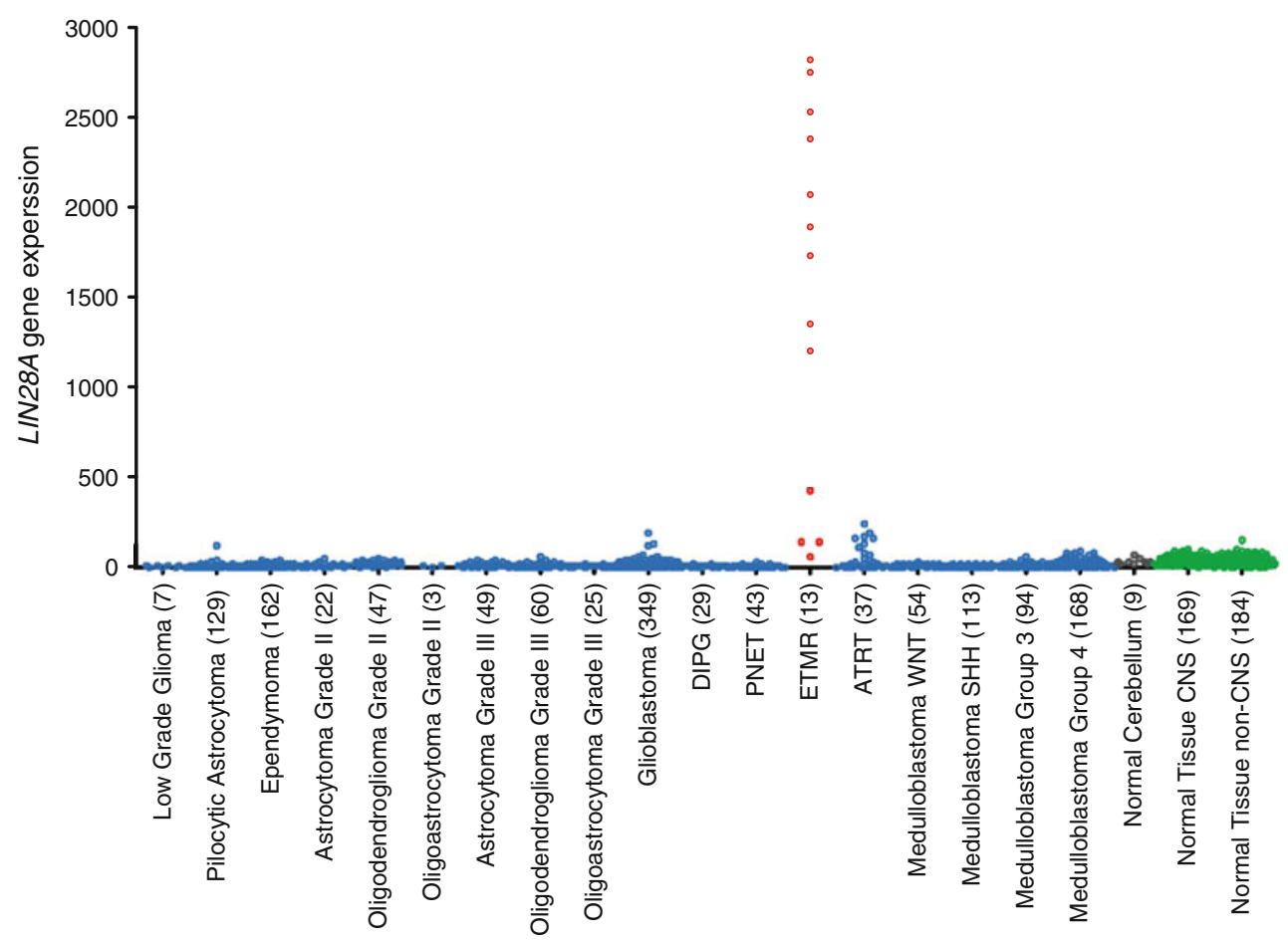

Fig. 1 LIN28A expression is highly upregulated only in ETMR cases when compared to other pediatric and adult brain tumors $(n=1404)$ and normal CNS and non-CNS tissues $(n=353)$. The numbers in parentheses indicate the number of samples for each entity. All data were generated on Affymetrix U133plus 2.0 arrays and were analysed using the microarray analysis and visualization platform R2 (http:// r2.amc.nl) 
not expressed at all in other pediatric and adult brain tumors. Normal CNS and non-CNS tissues also did not express LIN28A. These data strongly suggest that LIN28A expression could be exploited as a diagnostic biomarker to specifically detect ETMR. Interestingly, Picard et al. [20] recently analysed gene-expression profiles of $51 \mathrm{CNS}$ PNETs and identified 3 molecular subgroups, one of which was distinguished by high expression of LIN28A, frequent amplification of $19 \mathrm{q} 13.42$, young age, and dismal prognosis. Our data now suggest that all tumors in this subgroup fit well to the diagnosis of ETMR.

LIN28A and its homolog LIN28B encode proteins that bind small RNA and function as negative regulators of the let-7 family of miRNAs, which may act as tumor suppressor miRNAs [24]. LIN28A is a conserved cytoplasmic protein, but may be imported to the nucleus where it regulates the translation and stability of mRNA. In addition, LIN28A has been implicated in stem cell pluripotency and metabolism, is expressed widely in early embryogenesis, and is downregulated upon differentiation [7, 15]. Some recent studies suggest that $L I N 28 A$ and $L I N 28 B$ function as oncogenes promoting tumor transformation and progression, with high expression associated with unfavorable clinical course in cancers of the ovary, colon, esophagus, and sympathetic nervous system (neuroblastoma) [7, 15]. A potential mechanism for the oncogenic potency of LIN28A and LIN28B might be mediated through let-7 repression and consecutive upregulation or stabilization of let-7 targets, such as $M Y C(N), R A S, C D K 6$ and HMGA2 [12]. Of note, we indeed observed strikingly tight associations between expression levels of LIN28A and those of MYCN, NRAS, CDK6, and HMGA2 in the 13 ETMRs (Fig. 2). Moreover, recent data of Molenaar et al. [15] showed that $\operatorname{Lin} 28 B$ overexpression in the mouse sympathetic adrenergic lineage induced development of neuroblastomas marked by low let-7 miRNA and high MYCN expression. Interestingly, $L I N 28 B$ is also highly expressed in all 13 ETMRs, but its diagnostic utility is limited, given that it is also found in other brain tumors, including medulloblastoma.

To test whether LIN28A expression could be used as a sensitive and specific diagnostic marker for ETMR, we performed IHC screening of a large cohort of 816 malignant pediatric brain tumors (Table 1). Strong and diffuse LIN28A cytoplasmic immunostaining was found in all 37 histologically classic ETMR (Fig. 3). Thirty-six of these tumors $(97 \%)$ also harbored high-level amplification of the $19 q 13.42$ locus, which was not present in any other tumors analyzed (Table 1). LIN28A positivity was found to be more prominent and intense in multilayered rosettes and poorly differentiated small cell tumor areas, whereas only single collections of positive cells were observed within neuropil-like tumor parts. Analysis of nine ETMR
Fig. 2 Expression of LIN28A strongly and significantly correlates with expression of HMGA2 (a), MYCN (b), CDK6 (c), and NRAS in ETMR (d)
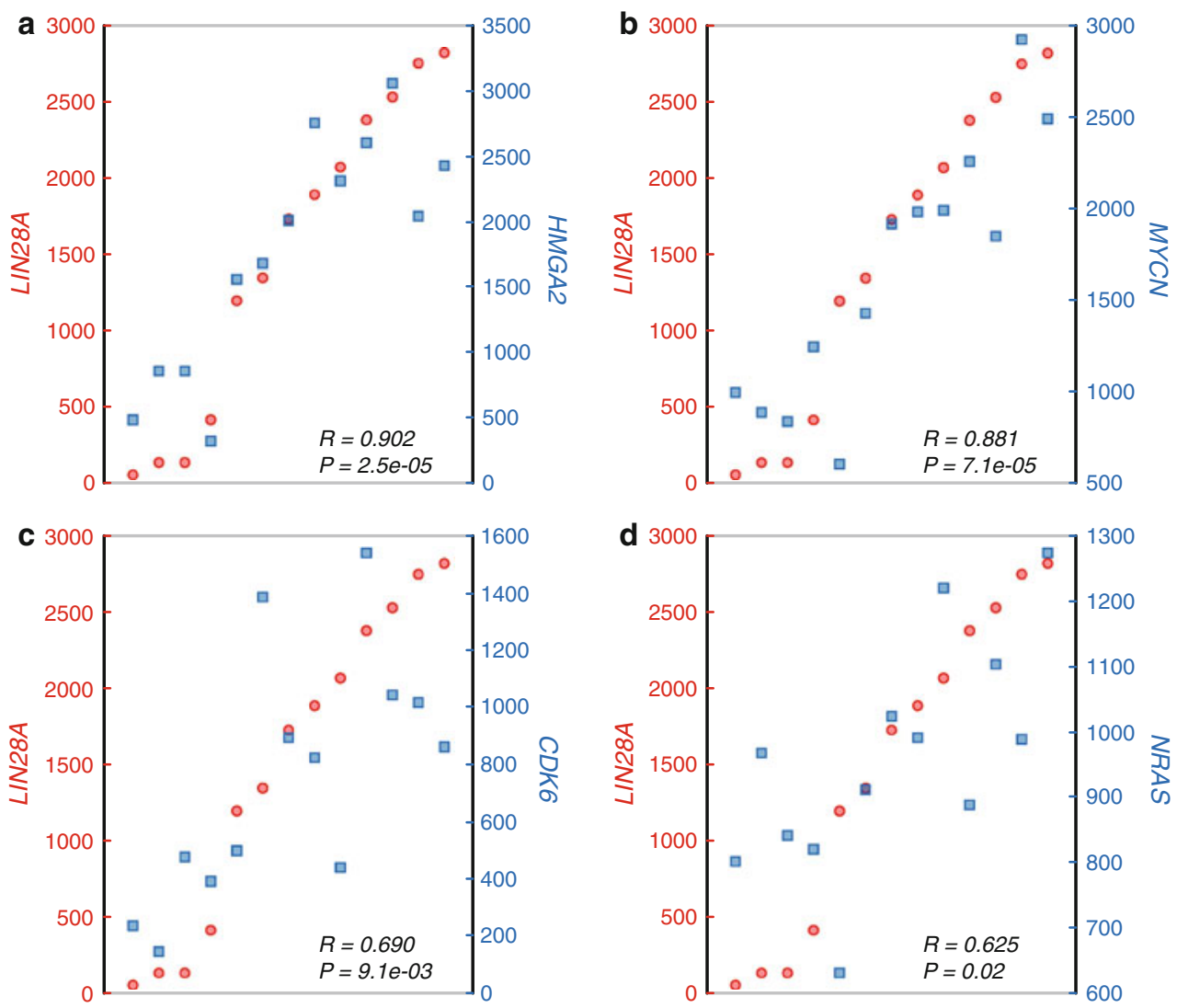


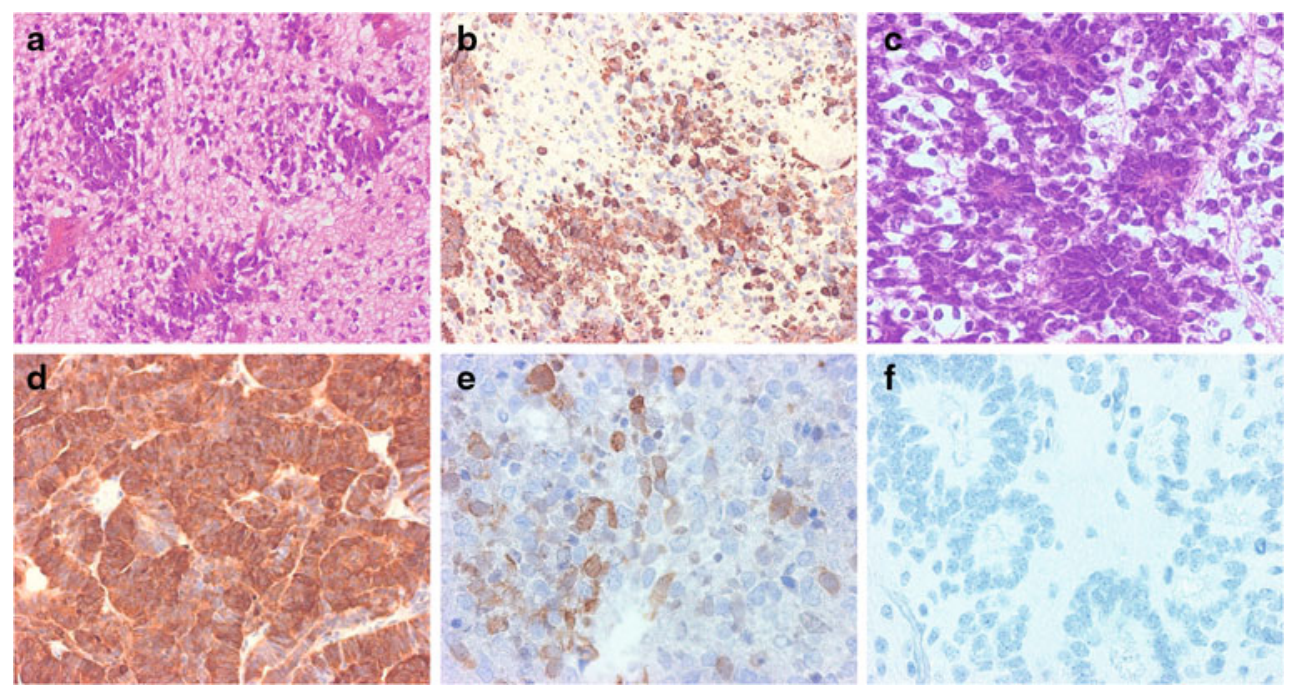

Fig. 3 LIN28A immunohistochemistry in pediatric malignant CNS tumors. Microscopic appearance of ETMR composed of clusters of multilayered rosettes embedded in abundant neuropil (initially diagnosed as ETANTR) (a). Intense LIN28A expression in poorly differentiated areas containing rosettes and the absence of expression in neuropil of tumor (b). Microscopic appearance of ETMR

samples obtained from corresponding tumor recurrences showed that the intensity of LIN28A immunoexpression and the number of stained cells were significantly higher in recurrent lesions in comparison to their primaries (Fig. 4). In addition, we had the opportunity to compare the results of LIN28A mRNA and protein expression for six ETMR samples (4 tumors with expression gene levels $>1,000$, and 2 samples with lower LIN28A expression). All these
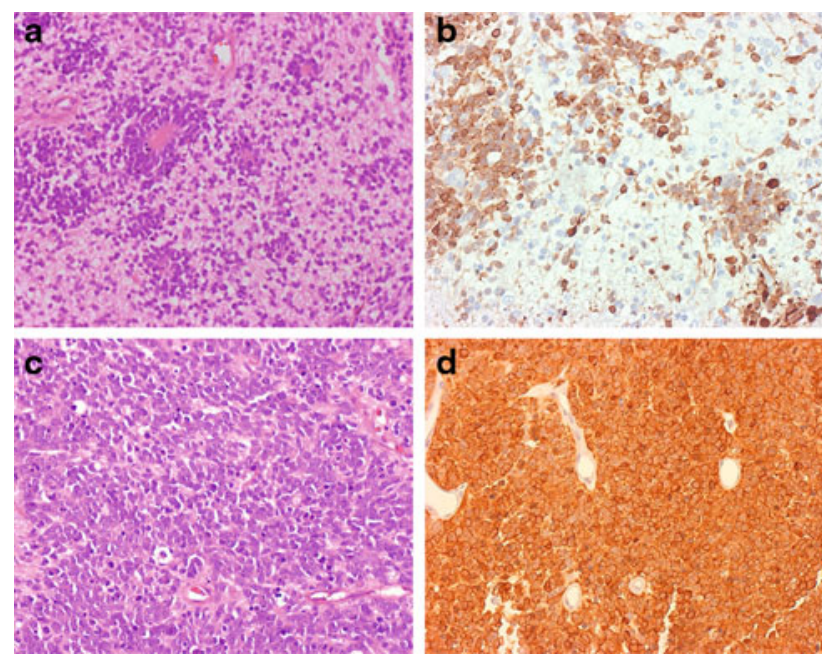

Fig. 4 LIN28A expression patterns in primary and recurrent ETMR. Primary ETMR with single multilayered rosettes and abundant neuropil (a). LIN28A expression is limited with rosettes and small cell collections (b). The ETMR relapse from the same patient is composed of hypercellular areas but lacks neuropil areas (c). Strong and diffuse LIN28A expression in all cells of the recurrent tumor (d) composed of numerous rosettes with clusters of small poorly differentiated cells (initially diagnosed as ependymoblastoma) (c). Strong and diffuse LIN28 expression in all parts of the tumor (d). AT/RT. Focal LIN28A expression in single collections of tumor cells (e). Anaplastic ependymoma. Immunonegativity for LIN28A in tumor region with numerous ependymal rosettes (f)

tumors showed clear LIN28A positivity. Nevertheless, the two ETMR samples with lower LIN28A mRNA expression levels contained extensive areas of LIN28A immunonegative neuropil, whereas the four tumors with high LIN28A mRNA expression were composed predominantly of LIN28A immunopositive, histologically primitive small cell areas.

Among the other tumor entities, focal cytoplasmic immunoexpression of LIN28A was only found in single cell collections of six AT/RT cases (12\%). Each of these six tumors had obvious losses of nuclear INI1 protein expression, in line with their initial histopathological diagnosis (Fig. 3). In contrast, all other pediatric CNS malignant tumors, including 44 additional AT/RT samples, 41 CNS PNETs, 334 medulloblastomas, 223 anaplastic ependymomas, and 131 pediatric glioblastomas were completely negative for LIN28A immunostaining (Fig. 3). Finally, we performed survival analysis for all these patients based on LIN28A reactivity (Fig. 5). Tumors with diffuse and wide-spread immunoexpression of LIN28A (considered as "positive" samples and representing all ETMR cases) showed an extremely poor overall survival (5-year overall survival estimate of $0 \%$ ) in comparison to other malignant pediatric brain tumors with absence or rare focal positivity of LIN28A (5-year survival $68 \%, \log$-rank $p<0.001$ ).

Therefore, this study represents a report of LIN28A as a highly specific and sensitive diagnostic marker for the distinct pathological verification of ETMR and, correspondingly, as a new important diagnostic tool to be routinely applied in all malignant childhood brain tumors 


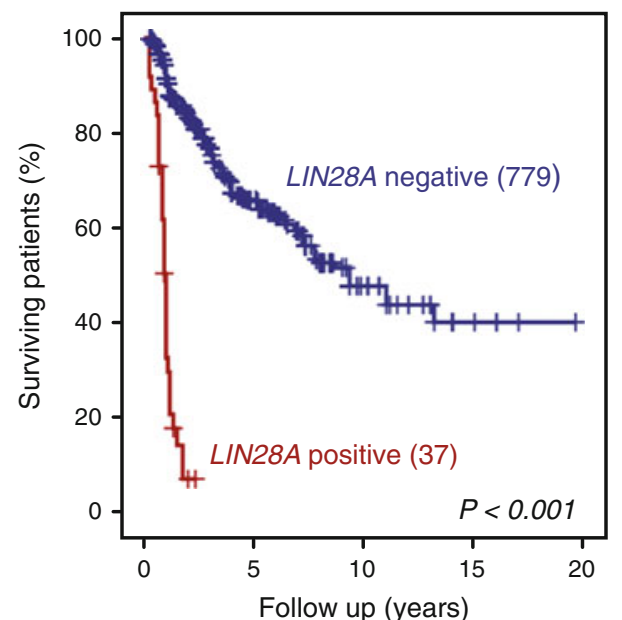

Fig. 5 Kaplan-Meier overall survival analysis for LIN28A positive malignant brain tumors versus LIN28A negative malignant brain tumors in children. Overall 5-year survival was $0 \%$ for LIN28A positive versus $68 \%$ for LIN28A negative tumors (log-rank, $p<0.001)$. Numbers on the Y-axis indicate the fraction of surviving patients. Numbers on the $X$ axis indicate the follow-up time in years

where ETMR may be considered a possible diagnosis. Variability of LIN28A gene expression in ETMR samples correlated closely with the intratumoral heterogeneity observed immunohistochemically. Focal positivity of LIN28A in a small subset of AT/RTs is not considered problematic when taking the simultaneous loss of INI1 expression into account, with the latter representing a fairly specific molecular marker for AT/RT. On the other hand, LIN28A immunoexpression has also been detected recently in CNS germ-cell tumors with diffuse staining patterns found in germinomas, embryonal carcinomas and yolk sac tumors but being only focal in immature teratomas [2]. Nevertheless, these tumors usually affect older children (apart from the some immature teratomas of infancy) than those at risk for ETMRs, are typically not situated in those locations commonly involved by ETMRs, and do not enter the differential diagnosis on histopathologic and immunohistochemical grounds.

Our current data also confirmed that ETMR is a unique clinico-pathologic entity from a molecular perspective, exhibiting 19q13.42 amplification and high levels of LIN28A expression accompanied by particularly aggressive clinical behavior. It will now be important to understand the biological consequence of overexpression of such universal and direct miRNA translation regulators as LIN28A and LIN28B in ETMR, taking into account the prototypic amplification of the oncogenic miRNA cluster at $19 \mathrm{q} 13.42$ in these tumors.

Acknowledgments Andrea Wittmann, Laura Sieber, and Linda Linke are acknowledged for excellent technical assistance and Dominik Sturm for help with the Figures. This study was supported by grants from the Dutch Cancer Foundations KWF (2010-4713) and KIKA to MK.
Open Access This article is distributed under the terms of the Creative Commons Attribution License which permits any use, distribution, and reproduction in any medium, provided the original author(s) and the source are credited.

\section{References}

1. Birks DK, Donson AM, Patel PR, Dunham C, Muscat A, Algar EM, Ashley DM, Kleinschmidt-Demasters BK, Vibhakar R, Handler MH, Foreman NK (2011) High expression of BMP pathway genes distinguishes a subset of atypical teratoid/rhabdoid tumors associated with shorter survival. Neuro Oncol 13(12):1296-1307. doi:10.1093/neuonc/nor140

2. Cao D, Liu A, Wang F, Allan RW, Mei K, Peng Y, Du J, Guo S, Abel TW, Lane Z, Ma J, Rodriguez M, Akhi S, Dehiya N, Li J (2011) RNA-binding protein LIN28 is a marker for primary extragonadal germ cell tumors: an immunohistochemical study of 131 cases. Mod Pathol Off J US Can Acad Pathol Inc 24(2):288-296. doi:10.1038/modpathol.2010.195

3. Eberhart CG, Brat DJ, Cohen KJ, Burger PC (2000) Pediatric neuroblastic brain tumors containing abundant neuropil and true rosettes. Pediatr Dev Pathol 3(4):346-352

4. Fattet S, Haberler C, Legoix P, Varlet P, Lellouch-Tubiana A, Lair S, Manie E, Raquin MA, Bours D, Carpentier S, Barillot E, Grill J, Doz F, Puget S, Janoueix-Lerosey I, Delattre O (2009) Beta-catenin status in paediatric medulloblastomas: correlation of immunohistochemical expression with mutational status, genetic profiles, and clinical characteristics. J Pathol 218(1):86-94. doi: 10.1002/path.2514

5. Gessi M, Giangaspero F, Lauriola L, Gardiman M, Scheithauer BW, Halliday W, Hawkins C, Rosenblum MK, Burger PC, Eberhart CG (2009) Embryonal tumors with abundant neuropil and true rosettes: a distinctive CNS primitive neuroectodermal tumor. The American journal of surgical pathology 33(2):211-217. doi:10.1097/PAS.0b013e318186235b

6. Gravendeel LA, Kouwenhoven MC, Gevaert O, de Rooi JJ, Stubbs AP, Duijm JE, Daemen A, Bleeker FE, Bralten LB, Kloosterhof NK, De Moor B, Eilers PH, van der Spek PJ, Kros JM, Sillevis Smitt PA, van den Bent MJ, French PJ (2009) Intrinsic gene expression profiles of gliomas are a better predictor of survival than histology. Cancer Res 69(23):9065-9072. doi: 10.1158/0008-5472.CAN-09-2307

7. Hamano R, Miyata H, Yamasaki M, Sugimura K, Tanaka K, Kurokawa Y, Nakajima K, Takiguchi S, Fujiwara Y, Mori M, Doki Y (2012) High expression of Lin28 is associated with tumour aggressiveness and poor prognosis of patients in oesophagus cancer. Br J Cancer 106(8):1415-1423. doi:10.1038/ bjc. 2012.90

8. Johnson RA, Wright KD, Poppleton H, Mohankumar KM, Finkelstein D, Pounds SB, Rand V, Leary SE, White E, Eden C, Hogg T, Northcott P, Mack S, Neale G, Wang YD, Coyle B, Atkinson J, DeWire M, Kranenburg TA, Gillespie Y, Allen JC, Merchant T, Boop FA, Sanford RA, Gajjar A, Ellison DW, Taylor MD, Grundy RG, Gilbertson RJ (2010) Cross-species genomics matches driver mutations and cell compartments to model ependymoma. Nature 466(7306):632-636. doi:10.1038/ nature 09173

9. Judkins AR, Ellison DW (2010) Ependymoblastoma: dear, damned, distracting diagnosis, farewell!*. Brain Pathol 20(1): 133-139. doi:10.1111/j.1750-3639.2008.00253.x

10. Kool M, Koster J, Bunt J, Hasselt NE, Lakeman A, van Sluis P, Troost D, Meeteren NS, Caron HN, Cloos J, Mrsic A, Ylstra B, Grajkowska W, Hartmann W, Pietsch T, Ellison D, Clifford SC, 
Versteeg R (2008) Integrated genomics identifies five medulloblastoma subtypes with distinct genetic profiles, pathway signatures and clinicopathological features. PLoS ONE 3(8):e3088. doi: 10.1371/journal.pone.0003088

11. Korshunov A, Remke M, Gessi M, Ryzhova M, Hielscher T, Witt H, Tobias V, Buccoliero AM, Sardi I, Gardiman MP, Bonnin J, Scheithauer B, Kulozik AE, Witt O, Mork S, von Deimling A, Wiestler OD, Giangaspero F, Rosenblum M, Pietsch T, Lichter P, Pfister SM (2010) Focal genomic amplification at 19q13.42 comprises a powerful diagnostic marker for embryonal tumors with ependymoblastic rosettes. Acta Neuropathol 120(2):253260. doi:10.1007/s00401-010-0688-8

12. Lee YS, Dutta A (2007) The tumor suppressor microRNA let-7 represses the HMGA2 oncogene. Genes Dev 21(9):1025-1030. doi:10.1101/gad.1540407

13. Li M, Lee KF, Lu Y, Clarke I, Shih D, Eberhart C, Collins VP, Van Meter T, Picard D, Zhou L, Boutros PC, Modena P, Liang ML, Scherer SW, Bouffet E, Rutka JT, Pomeroy SL, Lau CC, Taylor MD, Gajjar A, Dirks PB, Hawkins CE, Huang A (2009) Frequent amplification of a chr19q13.41 microRNA polycistron in aggressive primitive neuroectodermal brain tumors. Cancer Cell 16(6):533-546. doi:10.1016/j.ccr.2009.10.025

14. Louis DN, Ohgaki H, Wiestler OD, Cavenee WK, Burger PC, Jouvet A, Scheithauer BW, Kleihues P (2007) The 2007 WHO classification of tumours of the central nervous system. Acta Neuropathol 114(2):97-109. doi:10.1007/s00401-007-0243-4

15. Molenaar JJ, Domingo-Fernandez R, Ebus ME, Lindner S, Koster J, Drabek K, Mestdagh P, van Sluis P, Valentijn LJ, van Nes J, Broekmans M, Haneveld F, Volckmann R, Bray I, Heukamp L, Sprussel A, Thor T, Kieckbusch K, Klein-Hitpass L, Fischer M, Vandesompele J, Schramm A, van Noesel MM, Varesio L, Speleman F, Eggert A, Stallings RL, Caron HN, Versteeg R, Schulte JH (2012) LIN28B induces neuroblastoma and enhances MYCN levels via let-7 suppression. Nat Genet 44(11):11991206. doi:10.1038/ng.2436

16. Nobusawa S, Yokoo H, Hirato J, Kakita A, Takahashi H, Sugino $\mathrm{T}$, Tasaki K, Itoh H, Hatori T, Shimoyama Y, Nakazawa A, Nishizawa S, Kishimoto H, Matsuoka K, Nakayama M, Okura N, Nakazato Y (2012) Analysis of chromosome 19q13.42 amplification in embryonal brain tumors with ependymoblastic multilayered rosettes. Brain Pathol 22(5):689-697. doi:10.1111/j. 1750-3639.2012.00574.x

17. Paugh BS, Broniscer A, Qu C, Miller CP, Zhang J, Tatevossian RG, Olson JM, Geyer JR, Chi SN, da Silva NS, Onar-Thomas A, Baker JN, Gajjar A, Ellison DW, Baker SJ (2011) Genome-wide analyses identify recurrent amplifications of receptor tyrosine kinases and cell-cycle regulatory genes in diffuse intrinsic pontine glioma. J Clin Oncol 29(30):3999-4006. doi:10.1200/JCO. 2011.35.5677
18. Paugh BS, Qu C, Jones C, Liu Z, Adamowicz-Brice M, Zhang J, Bax DA, Coyle B, Barrow J, Hargrave D, Lowe J, Gajjar A, Zhao W, Broniscer A, Ellison DW, Grundy RG, Baker SJ (2010) Integrated molecular genetic profiling of pediatric high-grade gliomas reveals key differences with the adult disease. J Clin Oncol 28(18):3061-3068. doi:10.1200/JCO.2009.26.7252

19. Paulus W, Kleihues P (2010) Genetic profiling of CNS tumors extends histological classification. Acta Neuropathol 120(2):269270. doi:10.1007/s00401-010-0710-1

20. Picard D, Miller S, Hawkins CE, Bouffet E, Rogers HA, Chan TS, Kim SK, Ra YS, Fangusaro J, Korshunov A, Toledano H, Nakamura H, Hayden JT, Chan J, Lafay-Cousin L, Hu P, Fan X, Muraszko KM, Pomeroy SL, Lau CC, Ng HK, Jones C, Van Meter T, Clifford SC, Eberhart C, Gajjar A, Pfister SM, Grundy RG, Huang A (2012) Markers of survival and metastatic potential in childhood CNS primitive neuro-ectodermal brain tumours: an integrative genomic analysis. Lancet Oncol 13(8):838-848. doi: 10.1016/S1470-2045(12)70257-7

21. Robinson G, Parker M, Kranenburg TA, Lu C, Chen X, Ding L, Phoenix TN, Hedlund E, Wei L, Zhu X, Chalhoub N, Baker SJ, Huether R, Kriwacki R, Curley N, Thiruvenkatam R, Wang J, Wu G, Rusch M, Hong X, Becksfort J, Gupta P, Ma J, Easton J, Vadodaria B, Onar-Thomas A, Lin T, Li S, Pounds S, Paugh S, Zhao D, Kawauchi D, Roussel MF, Finkelstein D, Ellison DW, Lau CC, Bouffet E, Hassall T, Gururangan S, Cohn R, Fulton RS, Fulton LL, Dooling DJ, Ochoa K, Gajjar A, Mardis ER, Wilson RK, Downing JR, Zhang J, Gilbertson RJ (2012) Novel mutations target distinct subgroups of medulloblastoma. Nature 488(7409): 43-48. doi:10.1038/nature 11213

22. Roth RB, Hevezi P, Lee J, Willhite D, Lechner SM, Foster AC, Zlotnik A (2006) Gene expression analyses reveal molecular relationships among 20 regions of the human CNS. Neurogenetics 7(2):67-80. doi:10.1007/s10048-006-0032-6

23. Sun L, Hui AM, Su Q, Vortmeyer A, Kotliarov Y, Pastorino S, Passaniti A, Menon J, Walling J, Bailey R, Rosenblum M, Mikkelsen T, Fine HA (2006) Neuronal and glioma-derived stem cell factor induces angiogenesis within the brain. Cancer Cell 9(4):287-300. doi:10.1016/j.ccr.2006.03.003

24. Viswanathan SR, Daley GQ, Gregory RI (2008) Selective blockade of microRNA processing by Lin28. Science 320(5872): 97-100. doi:10.1126/science. 1154040

25. Woehrer A, Slavc I, Peyrl A, Czech T, Dorfer C, Prayer D, Stary S, Streubel B, Ryzhova M, Korshunov A, Pfister SM, Haberler C (2011) Embryonal tumor with abundant neuropil and true rosettes (ETANTR) with loss of morphological but retained genetic key features during progression. Acta Neuropathol 122(6):787-790. doi:10.1007/s00401-011-0903-2 